\title{
LOSSES OF NITRATE FROM A SANDY LOAM SOIL UNDER CORN:
}

LYSIMETER EXPERIMENT.

F. Cabrera, A. Reyes, E. Fernández-Boy, J.A. Cayuela. J.M. Murillo and F. Moreno. Instituto de Recursos Naturales y Agrobiología de Sevilla. (CSIC). Apartado 1052. 41080 Sevilla.

Additional index words: irrigation, Kjeldahl-N, drainage water, soil water content.

\section{Abstract}

Losses of nitrate from an undisturbed sandy loam soil contained in two monolith lysimeters, $\mathrm{L}_{0}$ and $\mathrm{L}_{1}$, (1 m diameter, $1.5 \mathrm{~m}$ deep) under corn and irrigation $(628 \mathrm{~mm})$ were studied. The crop was fertilized with $0\left(\mathrm{~L}_{0}\right)$ and $800\left(\mathrm{~L}_{1}\right) \mathrm{kg} \mathrm{N}$ ha-1. Water draining was collected periodically and analysed for nitrate content during the experimental period (20 March 91-23 March 92).

Mean values of nitrate concentration in the drainage water were 3.1 and 41.2 mg NO${ }_{3}-\mathrm{N} \mathrm{I}^{-1}$ in $\mathrm{L}_{0}$ and $\mathrm{L}_{1}$ respectively, the latter much higher than the limit imposed by the EC for potable water (11.3 mg N 1-1).

Three periods were distinguished during the experiment: i) Crop season, in which the total volume of water drained was 310 and $47 \mathrm{~mm}$ respectively in the $\mathrm{L}_{0}$ and $\mathrm{L}_{1}$, while the nitrate losses were of the same order in both lysimeters ( 21 and $17 \mathrm{~kg} \mathrm{~N} \mathrm{ha}^{-1}$, respectively); ii) Dry season, in which there was no water drainage; and iii) Rainy season, in which the total drained water was 157 and $139 \mathrm{~mm}$, and the nitrate losses 5 and $91 \mathrm{~kg} \mathrm{~N} \mathrm{ha-1} \mathrm{in} \mathrm{L}_{0}$ and $\mathrm{L}_{1}$ respectively.

The greater amount of water drained in $\mathrm{L}_{0}$ is due to the lower crop development (grain yield 4.4 and $21.3 \mathrm{t} \mathrm{ha}^{-1}$; total nitrogen plant uptake 69 and $400 \mathrm{~kg} \mathrm{~N} \mathrm{ha}^{-1}$, in $\mathrm{L}_{0}$ and $L_{1}$ respectively).

Total nitrate losses in $L_{1}$ account for $13 \%$ of the nitrogen fertilizer applied. Most of these losses occur in the rainy season.

At the end of the experimental period a decrease of the soil nitrate content was observed in both lysimeters.

\section{Introduction}

Production of heavy yields depends on the use of large quantities of inorganic fertilizers, which can imply an environmental risk: the pollution of groundwater by nitrate. Whatever form of nitrogen fertilizer is used, the end product in the soil is nitrate, which is vulnerable to being washed out of the soil by rain or irrigation. The most decisive factors determining the magnitude of nitrate leaching are nitrogen fertilization, climatic conditions, type of soil, soil management and type of crop (Gustafson, 1983; Duynisveld et al., 1988; Addiscott et al., 1991). 
Measurement of nitrate losses under field conditions is difficult. Five methods for measuring the concentration and fluxes of nitrate leaving the soil were outlined by Addiscott (1990). A good approach is the use of monolith lysimeter containing undisturbed soil (Dowdell et al., 1984; Owen, 1990, Bergström and Johansson, 1991).

The aim of this study was to evaluate timing and quantity of nitrate leaching in a highly fertilized soil under corn and irrigation using monolith lysimeters. These are preliminary results of a wider study lasting four years.

\section{Material and methods}

Two monolith lysimeters ( $1 \mathrm{~m}$ diameter, $1.5 \mathrm{~m}$ deep) were constructed without disturbing the soil profile and reinstalled in situ in a plot of 0.1 ha. The soil was a sandy loam XEROCHREPT $\left(\mathrm{pH}\left(\mathrm{H}_{2} \mathrm{O}\right) 7.2\right.$ and $7.1 ; \mathrm{CaCO}_{3} 5.2$ and $3.1 \%$; O.M. 0.88 and $0.69 \%$; Kjeldahl-N 599 and $454 \mathrm{mg} \mathrm{kg}^{-1} ; \mathrm{NO}_{3}-\mathrm{N} 7.5$ and $10.4 \mathrm{mg} \mathrm{kg}^{-1}$ at $0-50$ and $50-100 \mathrm{~cm}$ respectively. These are mean values of 45 samples). Lysimeters were provided with a system to collect drainage water $(1.2 \mathrm{~m}$ deep) and with access for neutron probe.

The lysimeters were sown with corn (170000 plant ha-1, 5 April 1991) and fertilized with $0\left(\mathrm{~L}_{0}\right)$ and $800 \mathrm{~kg} \mathrm{~N}^{-1}\left(\mathrm{~L}_{1}\right)$. Fertilizer was applied in three steps: a deep fertilization before sowing (22 March 1991) with $1000 \mathrm{~kg}^{\text {ha-1 }}$ with a 15-15-15 complex NPK fertilizer, and two top dressings with $400 \mathrm{~kg} \mathrm{ha}^{-1}$ (24 May 1991) and $1000 \mathrm{~kg} \mathrm{ha}^{-1}$ (7 June 1991) of urea (46\%) respectively. Lysimeters were periodically irrigated (EC $2.0 \mathrm{dS} \mathrm{m}^{-1}$; SAR $2.0 \mathrm{meq}^{12} \mathrm{l}^{-1 / 2} ; \mathrm{NO}_{3}-\mathrm{N}^{2} 10.5 \mathrm{mg} \mathrm{l}^{-1}$ ) receiving a total amount of water equivalent to $628 \mathrm{~mm}$. Water draining was collected periodically and analysed for nitrate during the experimental period (20 March 1991-23 March 1992) (figure 1). Nitrate in water was determined by ionic chromatography using a mixture of borate-gluconate $\mathrm{pH} 8.5$ as eluent. Soil water content and rainfall were also monitored throughout the experimental period (total rainfall equivalent to $293 \mathrm{~mm}$ (figure 1)).

Soil samples were collected at $0-30,30-60$ and $60-90 \mathrm{~cm}$ at the end of the experiment by means of a thin auger. Soil Kjeldahl-N was determined by the method described by Hesse (1971). Soil $\mathrm{NO}_{3}-\mathrm{N}$ was extracted by $0.2 \% \mathrm{Ca}(\mathrm{OH})_{2}$ suspension (Sims and Jackson, 1971) and the extracts analysed for $\mathrm{NO}_{3}-\mathrm{N}$ by the method of Scheiner (1974).

Plant height was measured periodically. Yield, mean weigth of ears and total Kjeldahl-N in kernel were determined at harvest.

\section{Results and Discussion}

Volumes of water drained by $\mathrm{L}_{0}$ are greater than those drained by $\mathrm{L}_{1}$, and both are related with the volumes of water supplied by irrigation and rainfall (figure 1). The total comulative volume of water drained by $\mathrm{L}_{0}$ is also greater than that by $\mathrm{L}_{1}$ (figure 2). Concentrations of $\mathrm{NO}_{3}-\mathrm{N}$ in drainage water ranged from $<1$ to 41.9 and $<1$ to 155 mg NO $3-\mathrm{N} \mathrm{l}^{-1}$ respectively in $\mathrm{L}_{0}$ and $\mathrm{L}_{1}$. Their mean values were 3.1 and $41.2 \mathrm{mg} \mathrm{NO}_{3}$ N 1-1 (figure 1), the latter being much higher than the 'maximum admissible concentration' imposed by the $\mathrm{EC}$ for potable water (11.3 $\mathrm{mg} \mathrm{NO}_{3}-\mathrm{N} \mathrm{1-1)}$. 
Three seasons can be distinguished during the experimental period: i) Crop season (20 March 1991-5 August 1991; ii) Dry season (6 August 1991-30 September 1991); iii) Rainy season (1 October 1991-23 March 1992).

During the 'crop season' the lysimeters received a total of 628 and $55 \mathrm{~mm}$ of water by irrigation and rainfall respectively. In this season total water drained was 310 and 47 $\mathrm{mm}$ respectively in $\mathrm{L}_{0}$ and $\mathrm{L}_{1}$, and total nitrate losses were of the same order in both lysimeters (21 and $17 \mathrm{~kg} \mathrm{NO}_{3}-\mathrm{N} \mathrm{ha}^{-1}$ respectively).

Analysing the hydric profiles of the lysimeters during the maximun development of the crop (figure 3), it can be observed that on 19 July 1991 (a few hours after the beginning of an irrigation), water content decreased throughout the soil profile down to 20 and $70 \mathrm{~cm}$ depth respectively in $\mathrm{L}_{0}$ and $\mathrm{L}_{1}$. Afterwards water content remained approximately constant at $0.227 \pm 0.008$ and $0.151 \pm 0.004 \mathrm{~cm}^{3} \mathrm{~cm}^{-3}$ (mean $\pm S D$ ) respectively in $L_{0}$ and $L_{1}$. Four days later (23 July 1991 ), water content at $0-80 \mathrm{~cm}$ in $\mathrm{L}_{0}$ and $0-60 \mathrm{~cm}$ in $\mathrm{L}_{1}$ decreased compared with the situation of $19 \mathrm{July} 1991$, and the shape of the hydric profile were similar for both lysimeters down to $70 \mathrm{~cm}$ depth. From $80 \mathrm{~cm}$ down in $\mathrm{L}_{0}$ and $70 \mathrm{~cm}$ in $\mathrm{L}_{1}$, water contents were nearly constant, $0.226 \pm 0.011$ $\mathrm{cm}^{3} \mathrm{~cm}^{-3}$ in $\mathrm{L}_{0}$ and $0.141 \pm 0.01 \mathrm{~cm}^{3} \mathrm{~cm}^{-3}$ in $\mathrm{L}_{1}$, values similar to those found at the same depth on 19 July. Therefore, during this irrigation event water content in the soil profile of $L_{0}$ is always greater than in that of $L_{1}$. The same situation was observed in all the irrigation events throughout the 'crop season'.

As total volume of water drained was greater in $L_{0}$ than in $L_{1}$ (figure 2), it is supposed that water depletion in $\mathrm{L}_{1}$ is mainly caused by the higher water uptake of the crop in this lysimeter because of the higher plant development. In fact, table 1 shows that corn plants of $L_{1}$ were toller than those of $L_{0}$, and that the yield, mean weight of ears and total Kjeldahl-N in kernel, was also greater in $\mathrm{L}_{1}$.

In the 'dry season' there was no water drainage and consequently no losses of nitrate in either of the lysimeters.

During the 'rainy season', total water drained in both lysimeters was similar, 157 and $139 \mathrm{~mm}$ in $\mathrm{L}_{0}$ and $\mathrm{L}_{1}$ respectively, 66 and $58 \%$ of the total rainfall in this period. However, in the same period nitrate losses in the drainage water were much higher in $\mathrm{L}_{1}\left(91 \mathrm{~kg} \mathrm{NO}_{3}-\mathrm{N} \mathrm{ha}^{-1}\right)$ than in $\mathrm{L}_{0}\left(5 \mathrm{~kg} \mathrm{NO}_{3}-\mathrm{N} \mathrm{ha}^{-1}\right)$. Nitrate losses in $\mathrm{L}_{1}$ during the 'rainy season' were the $11 \%$ of the $\mathrm{N}$ applied as fertilizer.

Total nitrate leached in $\mathrm{L}_{1}$ was $108 \mathrm{~kg} \mathrm{NO}_{3}-\mathrm{N} \mathrm{ha}^{-1}$, equivalent to $13 \%$ of the total nitrogen applied as fertilizer. This quantity is higher than that reported by Croll and Hayes (60-80 kg NO$\left.{ }_{3}-\mathrm{N} \mathrm{ha}^{-1}\right)$ for spring-sown cereals, and would be sufficient to constitute a serious threat to the maintenance of the EC-recommended level in groundwater (Foster et al., 1982).

At the end of the 'rainy season' it was found that the content of Kjeldahl-N throughout the profile decreased in $\mathrm{L}_{0}(5733 \mathrm{~kg} \mathrm{~N} \mathrm{ha-1})$ and increased in $\mathrm{L}_{1}(6396 \mathrm{~kg}$ $\mathrm{N} \mathrm{ha-1)}$ with respect to the average initial content of the soil $\left(6157 \mathrm{~kg} \mathrm{~N} \mathrm{ha}^{-1}\right)$, although neither of the differences was statistically significant $(\mathrm{P}<0.05)$ (figure 4). At the same time, nitrate content in the soil profile decreased significantly $(\mathrm{P}<0.05)$ with respect to the average initial content of the soil $\left(104 \mathrm{~kg} \mathrm{NO}_{3}-\mathrm{N} \mathrm{ha}^{-1}\right)$ in both $\mathrm{L}_{0}\left(23.8 \mathrm{~kg} \mathrm{NO}_{3}-\mathrm{N}\right.$ ha-1) and $\mathrm{L}_{1}\left(38.9 \mathrm{~kg} \mathrm{NO}_{3}-\mathrm{N} \mathrm{ha}^{-1}\right)$ (figure 4).

Figure 5 shows a balance of the nitrogen inputs and outputs in $\mathrm{L}_{0}$ and $\mathrm{L}_{1}$. It can be observed that at the end of the experimental period it was possible to determine the fate of most of the nitrogen of the system. In fact, in $\mathrm{L}_{0}$ the difference between the initial 
and final states (6327 and $5853 \mathrm{~kg} \mathrm{~N} \mathrm{ha}^{-1}$ respectively) was not significant $(\mathrm{P}<0.05)$ and accounts for some $7 \%$ of the nitrogen in the initial state. In $\mathrm{L}_{1}$ total nitrogen in the initial state was $7121 \mathrm{~kg} \mathrm{~N} \mathrm{ha}^{-1}$ and in the final one $6958 \mathrm{~kg}^{\mathrm{N}}$ ha-1, the difference being non-significant $(\mathrm{P}<0.05)$ and equal to some $2 \%$ of the nitrogen in the initial state. These differences, though non-significant, can be explained by the inherent error of the methods, losses by ammonia vaporization from urea, by denitrification, or even by the release of gaseous nitrogen (mainly ammonia) by the plants themselves.

\section{Acknowledgment}

Research carried out in the framework of contract No. STEP-CT90-0032-C (DSCN) of the CE.

\section{References}

Addiscott, T.M. 1990. Measurement of nitrate leaching: a review of methods. In: Nitrate-Agriculture-Eau (R. Calvet). INRA. Paris.

Addiscott, T.M., Whitmore, A.P., and Powlson, D.S. 1991. Farming, fertilizers and the nitrate problem. C.A.B. International. Wallingford.

Bergström, L, and Johansson, R. 1991. Leaching of nitrate from monolith lysimeters of different types of agricultural soils. J. Environ. Qual. 20: 801-807.

Croll, B.T., and Hayes, C.R. 1988. Nitrate and water supplies in the United Kingdom. Environ. Pollut. 50: 163-187.

Dowdell, R.J., Webster, C.P., Hill, D., and Mercer, E.R.1984. A lysimeter study of the fate of nitrogen in spring barley crops grown on a shallow soil overlying Chalk: crop uptake and leaching losses. J. Soil. Sci. 35: 183-190.

Duynisveld, W.H.M., Strebel, O, and Böttcher, J. 1988. Are nitrate leaching from arable land and nitrate pollution of ground water avoidable?. Ecol. Bull. 39: 116125.

Foster, S.S.D., Cripps, A.C., and Smith-Carrington, A. 1982. Nitrate leaching to groundwater. Phil Trans. Roy. Soc. 18: 103-116.

Gustafson, A., 1983. Leaching of nitrate from arable land into groundwater in Sweden. Environ. Geol. 5: 65-71.

Hesse, P.R. 1971. A textbook of soil chemistry analysis. John Murray Pub. Ltd. London.

Owens, L.B. 1990. Nitrate-nitrogen concentration in percolate from lysimeters planted to a legume-grass mixture. J. Environ. Qual. 19: 131-135.

Scheiner, D. 1974. A modified version of the sodium salicylate method for analysis of wastewater nitrates. Water. Res. 8: 935-840.

Sims, J.R., and Jackson, G.D. 1971. Rapid analysis of soil nitrate with chromotropic acid. Soil Sci. Soc. Amer. Proc. 35: 603-606. 
Table 1 - Mean values of corn plant height and results of corn performance at harvest.

\begin{tabular}{|c|c|c|c|c|c|}
\hline Lysimeter & $\begin{array}{l}\text { Plant } \\
\text { height } \\
18 \text { Jun } \\
\mathrm{cm}\end{array}$ & $\begin{array}{l}\text { Plant } \\
\text { height } \\
18 \mathrm{Jul} \\
\mathrm{cm}\end{array}$ & kg ha-1 & $\begin{array}{l}\text { Ear } \\
\text { mean } \\
\text { weight } \\
\mathrm{g}\end{array}$ & $\begin{array}{l}\text { Kernel } \\
\text { Total } \\
\text { Kjeldahl-N } \\
\%\end{array}$ \\
\hline $\begin{array}{l}\mathrm{L}_{0} \\
\mathrm{~L}_{1}\end{array}$ & $\begin{array}{r}70 a \\
136 b\end{array}$ & $\begin{array}{l}218 \mathrm{a} \\
247 \mathrm{~b}\end{array}$ & $\begin{array}{r}4415 \\
21295\end{array}$ & $\begin{array}{r}54.3 \mathrm{a} \\
187.3 \mathrm{~b}\end{array}$ & $\begin{array}{l}1.22 \\
1.53\end{array}$ \\
\hline
\end{tabular}

Values followed by different letters in the same column differ significantly $(\mathrm{P}<0.05)$.

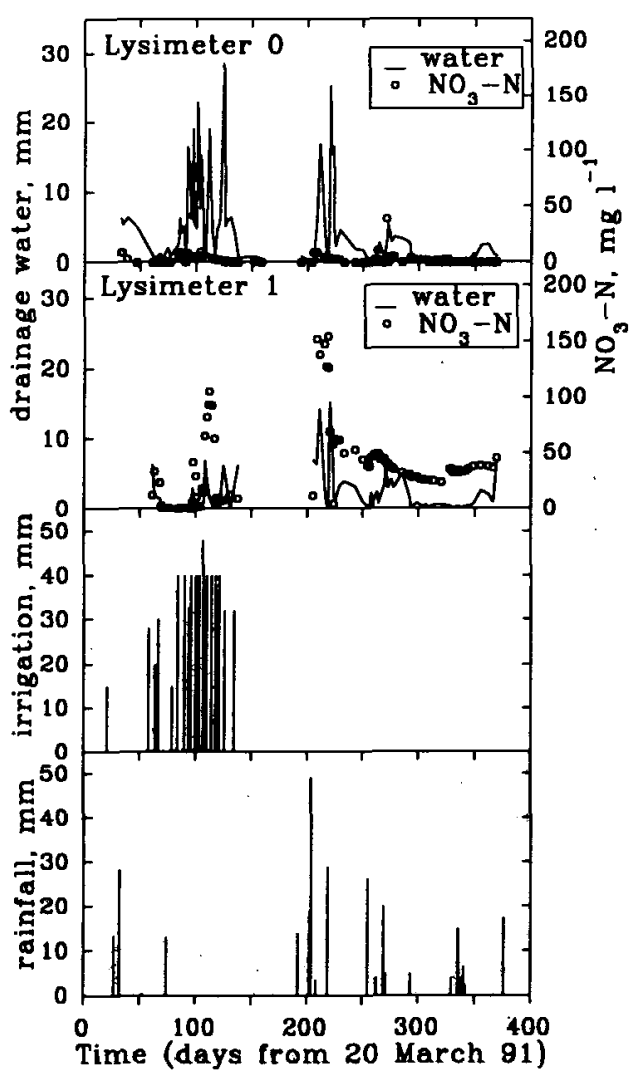

Figure 1 - Drained water, nitrate in drainage water, and irrigation and rainfall data.

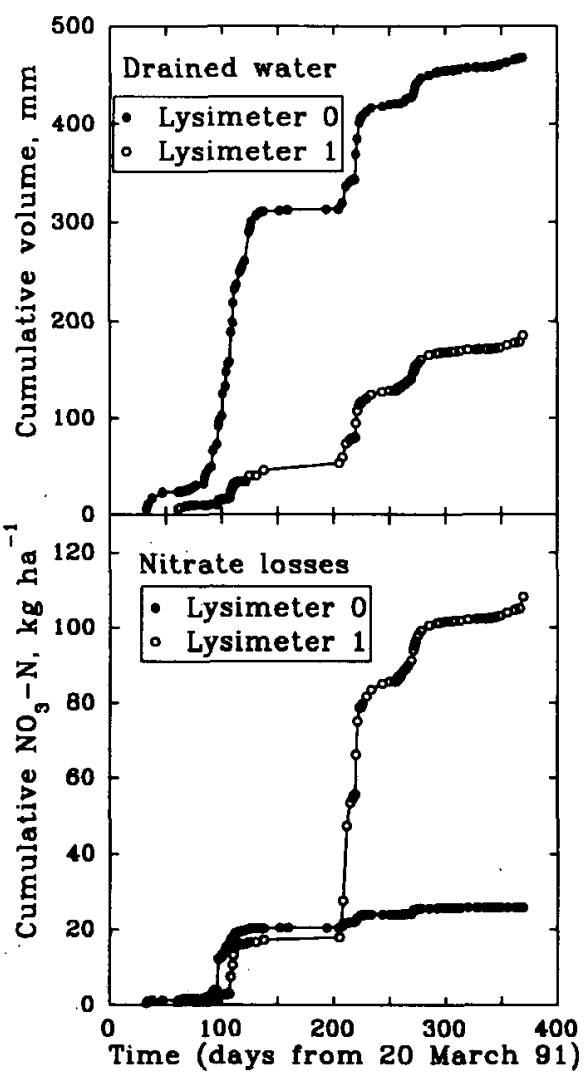

Figure 2 - Cumulative volume of drained water and cumulative nitrate losses. 


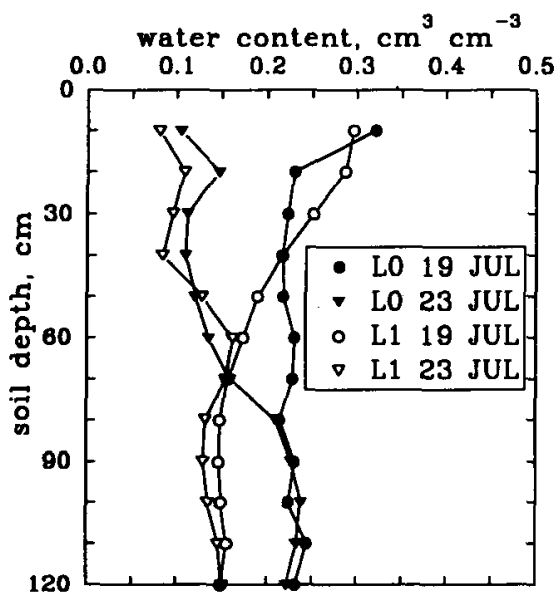

Figure 3 - Hydric profiles of the lysimeters.

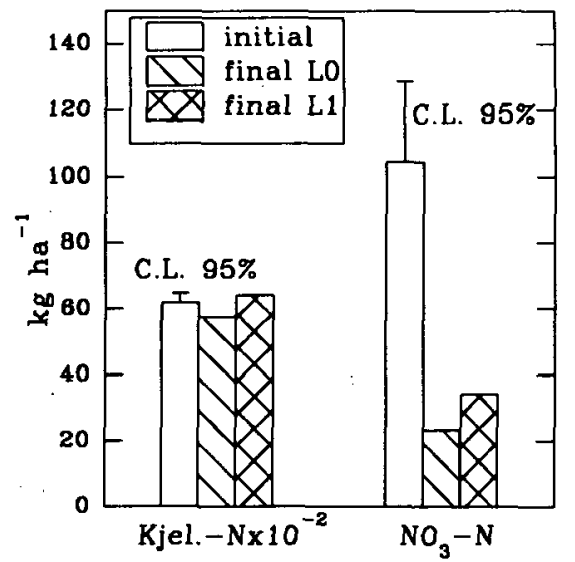

Figure 4 - Contents of Kjeldahl-N and $\mathrm{NO}_{3}-\mathrm{N}$ in the soils of the two lysimeters.

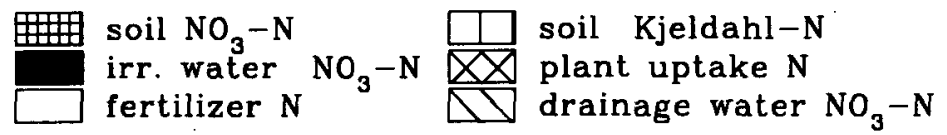

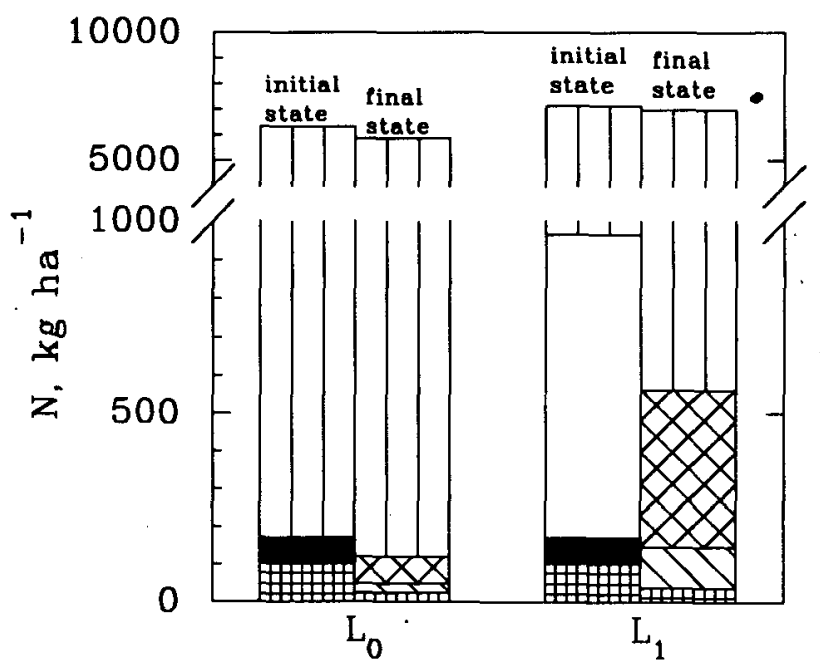

Figure 5 - Nitrogen balance. 